\title{
Correction: Combined sputum hypermethylation and eNose analysis for lung cancer diagnosis
}

Hubers AJ, Brinkman P, Boksem RJ, et al. Combined sputum hypermethylation and eNose analysis for lung cancer diagnosis. J Clin Pathol 2014;67:707-11.

The sentence published as "LDCT has established high sensitivity for lung cancer detection, as reported in the NLST, but has a high false-positivity rate of 97\%." should read "LDCT has established high sensitivity for lung cancer detection, as reported in the NLST, but has a high false positive rate of $24 \%$ and false-discovery rate of $96 \% . "$

(C) Author(s) (or their employer(s)) 2019. No commercial re-use. See rights and permissions. Published by BMJ.

J Clin Pathol 2019;72:839. doi:10.1136/jclinpath-2014-202414corr1

(D) Check for updates 